\title{
Previdência complementar fechada \\ - natureza e regime jurídico. Aspectos relevantes
}

\section{Resumo}

A Previdência Complementar Fechada, regime jurídico independente do Regime Geral da Previdência Social, encontra-se estabelecida pela Lei Complementar n⿳ำ 109/2001, cuja relação jurídica está adrede no Direito Privado, "imperium" da autonomia da vontade, tendo como pressuposto o princípio da contratualidade.

A análise do tema proposto considera os aspectos relevantes quanto à natureza e o regime jurídico da Previdência Complementar Fechada, abarcando, "primus", os preceitos filosóficos da teoria da contratualidade e, a "posteriori", a acepção moderna dos civilistas, atraindo o princípio da função social do contrato. "Ex positis", o propósito do disposto na Lei Complementar 109/2001.

\section{Abstract}

The Closed Complementary Welfare social system, as an independent juridical regimen of Social Welfare General Regimen, is established by the Complementary Law number 2001/ 109, which juridical relationship is intentionally in Private Right, "imperium" of the willing autonomy, having as presupposition the principle of Contractibility.

The analysis of the theme proposed considers the relevant aspects relating to nature and the juridical regimen of the Closed Complementary Welfare social system, comprehending "primus" the philosophical precepts of the contractibility theory and, "posteriori", the civilian's modern acceptation, by attracting the principle of contract social function. "Ex-positis" the purpose of the Complementary Law no 2001/109 dispositive.

\section{1- O Contratualismo}

O Renascimento, que marcou o despertar da cultura para um novo mundo de valores, é denominado pela idéia crítica de redução do conhecimento a seus elementos mais simples. Enquanto que na Idade Média existia um sistema ético subordinado a uma ordem transcendente, o homem renascentista procura explicar o mundo humano tão-somente segundo exigências humanas. ${ }^{1}$

Com isso, surgiram várias doutrinas - Grócio que em sua obra declara "que a justiça possui fundamento de razão, de maneira tão inamovível, que ela existiria mesmo que, por absurdo, Deus não existisse".

No Direito, surge um movimento sob a rubrica ambígua de Escola do Direito Natural, abrangendo inúmeros pensadores.

A Escola do Direito Natural ou do Jusnaturalismo distingue-se da concepção clássica do Direito Natural aristotélico-tomista por um motivo principal: enquanto em São Tomás "primeiro se dá a lei para depois se pôr o problema do agir segundo a lei", no Direito Natural, põe-se "primeiro o indivíduo com o seu poder de agir, para depois se pôr a lei."

Para o Renascimento, o dado primordial é o indivíduo, como ser capaz de pensar e de agir. Em primeiro lugar, está o indivíduo, com todos os seus problemas, com todas as suas exigências. "É da autoconsciência do indivíduo que vai resultar a lei". ${ }^{3}$

* Mestranda em Direito Previdenciário - PUC/SP. Professora da Associação Itaqueirense de Ensino. Professora dos cursos de Ciências Contábeis e Comércio Exterior das Faculdades Integradas "Campos Salles".

${ }^{1}$ REALE, Miguel. Filosofia do Direito. 14. ed. São Paulo: Saraiva, 1991.

${ }^{2}$ Idem, p. 644. 
Destarte, após o Renascimento, o processo de revelação jurídica vai do Direito Subjetivo para o Direito Objetivo (o sistema de normas). Na Idade Média, era o Direito Objetivo, a norma, que assinalava o ponto de partida da compreensão jurídica.

No entanto, o dado primordial passa a ser o homem mesmo, orgulhoso de sua força racional e de sua liberdade, capaz de constituir por si mesmo a regra de sua conduta. Nesse sentido, surge a idéia de Contrato.

O contratualismo é a alavanca do Direito na época moderna. Por que existe a sociedade? Por que existe o Direito? O Direito existe, respondem os jusnaturalistas, porque os homens pactuaram viver segundo regras delimitadoras dos arbítrios.

Da idéia do indivíduo em estado de natureza, sem leis, sem normas, surge a idéia da possibilidade de contratar. Da possibilidade de contratar deriva o fato do contrato; e, do contrato, a norma. Verifica-se que se opera uma inversão completa na concepção do Direito. Tudo converge para a pessoa do homem, enquanto homem em estado de natureza, concebido por abstração como anterior à sociedade. A sociedade é fruto do contrato, dizem alguns; enquanto que outros, mais moderados, limitarão o âmbito da gênese contratual: a sociedade é um fato natural, mas o Direito é um fato contratual. ${ }^{4}$

\section{1 - Modalidades de Contratualismo}

a) Contratualismo Total - Envolve a origem da sociedade e do Estado;

b) Contratualismo Parcial - Diz respeito ao Estado, sem abranger a origem da sociedade.

O contratualismo assumiu os aspectos mais diversos. a) contratualismo pessimista; b) contratualismo otimista.

Para Hobbes, o homem é um ser mau por natureza, somente preocupado com seus próprios interesses, e sem cuidados pelos interesses alheios, tendo se decidido a viver em sociedade, ao perceber que a violência era causadora de maiores danos. A sociedade ter-se-ia originado da limitação recíproca dos egoísmos.

Contrariamente a esse pessimismo, Jean Jacques Rousseau acreditava na bondade natural dos homens, que teriam vivido período paradisíaco, até o momento em que, pela má-fé de alguns, teriam sido levados a aceitar um pacto leonino de sociedade.

Para esse pensador, o homem natural é um homem bom que a sociedade corrompeu, sendo necessário libertá-lo do contrato de sujeição e privilégios, para se estabelecer um contrato social legítimo, conforme a razão. Ao contrato social e histórico, leonino, Rousseau contrapõe o contrato puro da razão. Daí duas obras que se completam: Discursos sobre a origem e os fundamentos da desigualdade entre os homens e Do contrato social ou Princípios do Direito Político. Na primeira, mostra os erros de contrato tal como foi constituído, em que os indivíduos foram vítimas dos mais fortes e dos mais astutos; na outra, passa a conceber a sociedade do futuro, oriunda de um contrato segundo as linhas puras da razão.

Conclusões: o contratualismo não é uma doutrina, mas um movimento que abrange várias teorias muitas vezes conflitantes.

a) Contratualismo Total - é aquele que acontece na obra de Hobbes ou de Rousseau, refere-se à origem da sociedade civil como a do Estado;

b) Contratualismo Parcial - Grócio - para quem a sociedade é um fato natural; aparece, porém, o Direito Positivo como resultado de um acordo ou de uma convenção. Para o mestre, o Direito Natural - que uma expressão da moral, segundo ensinamentos tradicionais, por ele ainda acolhidos - não possui fundamento contratual, mas o Direito Positivo, este sim é a expressão de um contrato. Neste caso, o "contrato" vale como categoria distintiva entre o mundo da moral, equiparado ao Direito Natural, e o mundo jurídico, só este resultante de convenção. Em

${ }^{3}$ Ibid., p. 646.

${ }^{4}$ Ibid., p. 646. 
suma, enquanto a moral é natural, o Direito é convencional.

Cabe, ainda, discursar sobre a distinção no campo do contratualismo quanto à natureza do homem contratar.

Nesse sentido, para alguns pensadores, o homem é concebido como um ser egoísta e violento, daí sua luta sem tréguas no estado selvagem, superado por uma convenção. Esse é o contratualismo pessimista, que acaba sempre na apologia de um Estado forte ou de um Estado identificado com a justiça em si mesmo. Essa é a oposição à posição de Hobbes, para quem a lei é a justiça, e o monarca é a expressão do justo. Para o autor do Leviatã, o Direito e o justo surgem depois do contrato, quando as forças se autolimitam e se disciplinam.

Logo, em seguida, o contratualismo otimista de Rousseau idealiza o homem natural corrompido por um falso contrato social.

Daí a teoria do radicalismo democrático, pregando o pleno governo do povo pelo povo, de maneira direta, sem qualquer intermediário, sem alienar o cidadão a sua liberdade, nem mesmo pela constituição de um mandatário para representá-lo nos Parlamentos...

Contudo, no meio dessas duas teses extremadas, temos a tese de Locke, que consolida seu pensamento "achando que o homem no estado da natureza já possui um direito que é anterior ao contrato, o direito de liberdade, condição para a feitura do pacto".

O homem nasce livre e por ser livre pode pactuar; de maneira que o contrato seria sempre condicionado pela liberdade e pela projeção da liberdade no mundo exterior, como fundamento da propriedade.

Ainda, o contratualismo comporta outra distinção, segundo a natureza do contrato mesmo, pelo que pode ser histórico ou deontológico.

Da passagem da época medieval para a renascentista, o contrato apresenta-se com a força de um fato histórico. Adotaram essa tese Grócio e Altúsio.

Diversamente de Rousseau e Hobbes, para esses pensadores o contrato desempenha apenas uma função de natureza lógica. Eles procuram indagar das condições da ordem jurídica, focali- zando o problema da autoridade, da liberdade, da obediência à lei, e são levados a recorrer à idéia de contrato como um elemento explicativo da sociedade e do Direito - é o contrato como critério deontológico.

O contrato não é um fato histórico, mas um critério de explicação da ordem jurídica. Para Rousseau, as suas observações não devem ser tomadas no sentido efetual e histórico, mas sim em sentido hipotético. Vivemos "como se" tivesse havido um contrato; e a sociedade legítima é aquela que se desenvolve tendo como pressuposto lógico a idéia de um contrato concluído segundo puras exigências racionais.

Essa doutrina, na concepção de Kant, atinge um grau mais alto ainda, pois o contrato adquire mero significado lógico-transcendental. Para Kant, "o homem é um ser que desde seu nascimento possui um direito inato, o direito de liberdade".

O contrato para Kant aparece como uma condição transcendental, sem a qual seria impossível a experiência mesma do Direito. O Conceito de contrato torna possível a experiência jurídica: - donde a sua definição do Direito como "o conjunto das condições mediante as quais o arbitrio de cada um se harmoniza com os demais, segundo uma lei geral de liberdade".

Ainda como preleciona Miguel Reale em sua obra (1991: a 651) "Em nossa tese sobre os Fundamentos do Direito, pensamos ter demonstrado que há um contratualismo implícito, de ordem lógico-transcendental, na doutrina jurídica de Kelsen, que chegou a invocar, como pressuposto de toda a ordem jurídica, o princípio de que 'pacta sunt servanda', assim como também a persistência de elementos contratualistas em teorias aparentemente opostas, como a do 'reconhecimento' de Bierling e certas colocações de Duguit."

\section{2- Conceito de Contrato}

Primeiramente, passamos a transcorrer sobre o tema, no âmbito do direito alienígina, como bem salienta Ś́lvio de Salvo Venosa (2001:327):

O contrato, no sistema francês, é posto como o ponto máximo do individualismo. O contrato vale e 
é obrigatório, porque assim foi desejado pelas partes. Nesse sentido, diz o art. 1.134 do Código Francês: "As convenções feitas nos contratos formam para as partes uma regra à qual deve se submeter como a própria lei". Não há outras limitações para o contrato que não aquelas fundadas em interesse público.

No Direito Alemão (VENOSA, 2001:328), prepondera o elemento vontade, elemento básico da definição. Assim, torna-se inimaginável o estudo do contrato sem o estudo prévio da teoria geral dos negócios jurídicos (e, naturalmente, a exata conceituação de fato jurídico, ato jurídico e ato ilícito).

\section{Continuando a idéia:}

Na liberdade de manifestação da vontade, situa-se o baluarte da autonomia da vontade e, portanto, do direito privado. As injunções sociais colocam hoje em xeque a autonomia negocial e contratual. $\mathrm{O}$ espirito clássico do contrato dá lugar aos contratos de massa, que exigem ora a intervenção do poder do Estado em suas normas, ora a imposição de um contrato previamente redigido, imposto a um número indeterminado e crescente de sujeitos. Dessa chamada crise no contrato. Adiante-se, contudo, que o ideal de abstenção do Estado na relação negocial privada fica cada vez mais distante. Não podemos, porém, deixar que o intervencionismo do poder, estatal ou econômico, elimine um mínimo de vontade no contrato, sob pena de extinguirse uma das mais legitimas liberdades individuais.

Na doutrina pátria (RODRIGUES, 2002: v.3:9):

Os negócios bilaterais, isto é, os que decorrem com o acordo de mais de uma vontade, são os con- tratos. Portanto, o contrato representa uma espécie do gênero negócio jurídico. E a diferença específica entre ambos consiste na circunstância de o aperfeiçoamento do contrato depender da conjunção da vontade de duas ou mais partes.

\section{Maria Helena Diniz $z^{5}$ conceitua:}

...é o acordo de duas ou mais vontades, na conformidade da ordem jurídica, destinado a estabelecer uma regulamentação de interesses entre as partes, com o escopo de adquirir, modificar, ou extinguir relações jurídicas de natureza patrimonial.

Diante da conceituação, podemos firmar que o âmbito do contrato não se circunscreve apenas ao Direito das Obrigações, conforme posto no Código Civil Brasileiro, estendendo-se aos outros ramos do Direito Privado e mesmo do Direito Público, até mesmo em relações jurídicas que se estabeleçam mediante acordo de vontades e fora do terreno patrimonial, embora uma parte considerável da doutrina procure limitar o conceito de contrato, em sentido estrito, aos ajustes que constituam, regulem ou extinguam relações patrimoniais. Nesse sentido, é o pensamento de Maria Helena Diniz.

Numa concepção moderna e atual Alinne Arquette Leite Novais em Teoria contratual e o Código de Defesa do Consumidor (2001:33):

O contrato surgiu como uma exigência da realidade social. Surgiu como forma de regulamentação jurídica das operações econômicas que possibilitam a circulação das riquezas. Assim é que o contrato, em um primeiro momento, pode ser visto sob dois aspectos, como muito bem salienta Enzo Roppo, isto é, contrato como operação econômica e contrato como conceito jurídico. ${ }^{6}$

${ }^{5}$ DINIZ, Maria Helena. Curso de Direito Civil Brasileiro: direito das coisas. De acordo com o novo Código Civil (Lei nº 10.406, de 10-1-2002). 17 ed. v.3. São Paulo: Saraiva, 2002.

${ }^{6}$ ROPPO, Enzo. O contrato. cit., p. 7-10. Segundo este autor, o contrato admite duas acepçóes: primeiro, de contrato como operação econômica, já que "as situações, as relações, os interesses que constituem a substância real de qualquer contrato podem ser resumidas na ideia de operação econômica. De facto, falar de contrato significa sempre remeter - explícita ou implicitamente, directa ou mediatamente - para a idéia de operação econômica"; e depois, de contrato como um conceito jurídico, assim dizendo: "em contextos lingüísticos diferentes, ao contrário, fala-se de contrato na acepção técnico-jurídica do vocábulo, e isto para aludir às implicações e às conseqüências legais que o sistema das normas de códigos ou de leis especiais e das regras efectivamente aplicadas pelos juízes, liga à efectivação de uma certa operação econômica, ou então, para indicar as elaborações doutrinais construídas pela ciência jurídica sobre aquelas normas e aquelas regras". (op. cit., p.8). 
Desse modo, a grande quantidade de operações econômicas fez surgir o fenômeno da contratualização, no sentido de organizar tais modos de circulação de riquezas através da regulamentação jurídica, fazendo surgir, conseqüentemente, um

...conjunto - historicamente mutável - das regras e dos princípios, de vez em quando escolhidos para conformar, duma certa maneira, aquele instituto jurídico, $e$, portanto, para dar um certo arranjo - funcionalizado a determinados fins e determinados interesses - ao complexo das operações econômicas efectivamente levadas a cabo, dando origem ao Direito Contratual.

Diante dessa argumentação, podemos dizer que, uma vez que o contrato está sempre ligado às operações econômicas, se o contrato não existisse, tais operações ficariam estagnadas e a circulação de riquezas ficaria comprometida. Daí dizer que o contrato possui uma função econômica.

Como preleciona Cláudia Lima Marques (RT, 1998, v. I, p.36) "o valor decisivo do contrato está, portanto, em ser o instrumento jurídico que possibilita e regulamenta o movimento de riquezas dentro da sociedade".

\section{1 - Função Social do Contrato}

Por outro lado, o contrato, também possui uma função social, já que ele aproxima os homens e abate suas diferenças, posto que, firmado pelo acordo de vontades (princípio consensualista), torna-se obrigatório o seu cumprimento pelas partes.

Marta Maria Vinagre, no artigo "A outra face do contrato"(Revista de Direito Civil 44/106, São Paulo: RT, 1988), também se pronuncia a respeito da função social do contrato, e o faz da seguinte forma:

E sem esquecer que uma nova ordem se instala no campo dos contratos, exigindo uma perspectiva nova quanto aos seus aspectos, nova ordem esta representada pela função social que o contrato deve exercer, que, ad instar do que aconteceu com a propriedade, tem marcado a sua existência, notadamente pelo dirigismo contratual, cada vez mais intenso, pela influência cada dia presente do Poder Público no domínio das atividades privadas e pelo princípio da boa-fé. Treu und Glauben.

Em face de tal conceito, ensina Silvio Rodrigues (2002: v. 3:11) citando Messineo, "o contrato exerce uma função e apresenta um conteúdo constante - o de ser o centro da vida dos negócios".

Nesse sentido, apoia-se na idéia de que o direito contratual foi um dos instrumentos mais eficazes da expansão capitalista em sua primeira etapa. ${ }^{7}$

\section{2 - Elementos Constitutivos e \\ Pressupostos de Validade do Contrato}

É o contrato um ato jurídico bilateral. Sendo os elementos constitutivos do ato jurídico: a) a vontade manifestada por meio da declaração; b) a idoneidade do objeto; c) a forma, quando da substância do ato. Quanto aos pressupostos de validade: a) a capacidade das partes e sua legitimação para o negócio; b) a liceidade do objeto; c) a obediência à forma, quando prescrita em lei.

Nesse sentido, lembra Silvio Rodrigues (2002:13) "Messineo cuida dessa matéria em seu livro doctrina general del contrato, já citado, sob o título de "Elementos e pressupostos do contrato" (v. I, Cap. II). Os elementos constitutivos ou intrínsecos do contrato são, a seu ver, o "consentimento, a causa lícita, a prestação (possível, lícita e determinável), a forma (quando requerida ad substantia) e, na hipótese do art. 1.145 do Código Civil Italiano, o motivo lícito".

\footnotetext{
${ }^{7}$ Cf. San Tiago Dantas, "Evolução contemporânea do direito contratual", RT, 195/144. Ainda desse eminente professor e relativamente à função social do contrato, não posso furtar-me de transcrever o seguinte magistério: "O direito contratual do início do século XIX forneceu os meios simples e seguros de dar eficácia jurídica a todas as combinações de interesses, aumentou, pela eliminação quase completa do formalismo, o coeficiente de segurança das transações; abriu espaço à lei da oferta e da procura, levando as restrições legais à liberdade de estipular; e se é certo que deixou de proteger os socialmente fracos, criou oportunidades amplas para os socialmente fortes, que emergiam de todas as camadas sociais, aceitando riscos e fundando novas riquezas".
} 
Ao lado de tais elementos há os pressupostos de validade, que são extrínsecos. Tais são: a capacidade para agir, o poder de dispor " $y$ aquel outro presupuesto (cuya atonimía, sin embargo, se puede poner in duda) que se há denominado legitimación para contratar".

Ensina que a falta de um elemento constitutivo produz a nulidade do negócio (art. 1418, inc. II, do Cód. Italiano), enquanto a falta de um pressuposto de validade conduz à nulidade da avença ou à sua ineficácia.

Orlando Gomes, em seu primeiro livro sobre contratos (Rio de Janeiro 1959), também consagra capítulo (3) à matéria: "Pressupostos são os elementos extrínsecos do negócio, ou seja, capacidade das partes, idoneidade do objeto e legitimação para realizálo. Requisitos são elementos indispensáveis à validade do ajuste e consistem no acordo e na forma". Observa ainda esse escritor que, "como os pressupostos e os requisitos se completam, são comumente confundidos, apesar de constituírem categorias diversas".

O fator novo, elementar ao conceito de contrato, é a coincidência de vontades, quer dizer, o acordo entre dois ou mais participantes da convenção.

\section{3 - Princípios do Direito Contratual}

Seis princípios básicos constituíram o alicerce da teoria contratual:

2.3.1 - O princípio da autonomia da vontade, apenas limitado pela supremacia da ordem pública;

2.3.2 - O princípio da relatividade das convenções;

2.3.3 - O princípio da força vinculante do contrato, ou da obrigatoriedade das convenções;

2.3.4 - O princípio do consensualismo;

2.3.5 - O princípio da igualdade;

2.3.6 - O princípio da boa-fé.

Passemos à análise dos princípios:

2.3.1 - Princípio da autonomia da vontade consiste na prerrogativa conferida aos indivíduos de criarem relações na órbita do Direito, desde que se submetam às regras impostas pela lei e que seus fins coincidam com o interesse geral, ou não contradigam. Assim, qualquer pessoa capaz pode, pela manifestação de sua vontade, tendo objeto lícito, criar relações a que a lei empresta validade.

Este princípio se desdobra em dois outros: a) princípio da liberdade de contratar ou não contratar; b) princípio da liberdade de contratar aquilo que entender.

Segundo Alinne Novais (2001:56), "tal princípio, que significa a possibilidade de que os particulares criem livremente direitos e obrigações para reger suas relações uns com os outros" ${ }^{8}$, se traduz na liberdade de celebrar ou não um contrato, na liberdade de escolha do parceiro contratual, na liberdade de escolha do tipo contratual e na liberdade de fixação do conteúdo do contrato, já que, conforme nos esclarece Enzo Roppo, com base na idéia de liberdade de contratar.

Afirmava-se que a conclusão dos contratos, de qualquer contrato, devia ser uma operação livre para os contraentes interessados: deviam ser estes, na sua soberania individual de juízo e de escolha, a decidir se estipular um certo contrato, a estabelecer se concluí-lo com esta ou com aquela contraparte, a determinar com plena autonomia o seu conteúdo, inserindo-lhe estas ou aquelas cláusulas, convencionando este ou aquele preço.

No entanto, este princípio sofre restrições, na concepção liberal, em face de normas ditadas pelo Estado - normas de ordem pública.

No mais, aos poucos o Estado começa a modificar a sua postura perante as relações interprivadas, ou seja, deixa de ser mero espectador e passa a efetivo interventor em tais relações, com o intuito de garantir justiça contratual, o que culminou com a chamada nova teoria contratual.

Assim, depreende-se, numa posição epistemológica, que a liberdade consinta ao indivíduo que contratar o que entender sofre limitações na idéia de ordem pública, pois, cada vez que o interesse individual colide com o da sociedade, é o desta última que deve prevalecer.

Nisto, a idéia de ordem pública é constituída por aquele conjunto de interesses jurídicos e morais

${ }^{8}$ Alinne cita Rachel SZTAJAN . Contrato de sociedade e formas societárias. São Paulo: Saraiva, 1989. p.4. 
que incumbem à sociedade preservar. Por conseguinte, os princípios de ordem pública não podem ser alterados por convenção entre os particulares.

Dessa forma, a noção de ordem pública e o respeito aos bons costumes constituem, conseqüentemente, barreiras limitadoras da liberdade individual em matéria de contrato.

No mais, nos termos do atual Código Civil, no art. 421, "A liberdade de contratar será exercida em razão e nos limites da função social do contrato". Com isso está repelido o individualismo e abarcado o interesse coletivo.

Ensina Maria Helena Diniz ${ }^{9}$ :

(...) nítida é, como diz Francisco Amaral, a função institucional do contrato, visto que limitada está a autonomia da vontade pela intervenção estatal, ante a função econômico-social daquele ato negocial, que o condiciona ao atendimento do bem comum e dos fins sociais. Amputam-se, assim, os excessos do individualismo e da autonomia da vontade. Como a lei não define a locução "função social do contrato", poderá ela ser interpretada de formas diversas, conduzindo à declaração de nulidade de cláusula ou até mesmo de toda a avença. Por isso, procuramos delinear alguns parâmetros a serem seguidos, pois, com essa função social do contrato, teremos o justo processo legal substantivo. E nenhuma convenção prevalecerá, se contrariar preceitos de ordem pública, tais como os estabelecidos por este Código para assegurar a função social dos contratos (CC, art. 2.035, parágrafo único). Assim, os contraentes deverão sujeitar sua vontade: a) às normas de ordem pública, que fixam, atendendo os interesses da coletividade, as bases jurídicas fundamentais em que repousam a ordem econômica e moral da sociedade, uma vez que são atinentes ao estado e à capacidade das pessoas; à organização da família; aos princípios básicos da ordem de vocação hereditária, da sucessão testamentária, do básico da ordem vocação hereditária, da sucessão testamentária, do direito de propriedade, da responsabilidade civil, da liberdade e da igualdade dos cidadãos, da liberdade de trabalho, de comércio e de indústria; à organização política, administrativa e econômica do Estado; e b) aos bons costumes, relativos à moralidade social, de forma que sejam proibidos, por exemplo, contratos que versem sobre exploração de casas de tolerância, corretagem matrimonial, usura, por contrariarem os bons costumes.

2.3.2 - Princípio da relatividade dos efeitos contratuais - ainda, como corolário do dogma da autonomia da vontade, este princípio quanto aos seus efeitos, somente atinge a esfera das partes contratantes, não podendo criar direitos ou obrigações para terceiros, por ausência absoluta de manifestação da vontade destes.

Desse modo, os efeitos internos do contrato vinculam as partes contratantes, e somente elas, não aproveitando nem prejudicando terceiros.

Para entender o princípio, é importante fixar a noção de terceiro conforme Orlando Gomes: "Como tal se considera quem quer que seja totalmente estranho ao contrato ou à relação sobre a qual ele estende os seus efeitos".

Prossegue, Alinne Novais (2002:62):

Tal princípio, assim como os demais reflexos do dogma da autonomia da vontade já analisados, foi sofrendo restrições, pelo surgimento de novos tipos de contratos, as chamadas estipulações em favor de terceiros, cujo exemplo mais marcante é o contrato de seguro de vida, através do qual se estipulam vantagens a favor de uma determinada pessoa que não participou, em momento algum, da formação do contrato, não tendo, portanto, concorrido com a sua vontade para a formação do vínculo contratual.

2.3.3 - Princípio da força vinculante das convenções - de acordo com este princípio, o contrato, uma vez obedecidos os requisitos legais, torna-se obrigatório entre as partes, que dele não podem desligar-se senão por outra avença em tal sentido. $\mathrm{O}$ contrato constitui-se numa lei privada entre as partes, adquirindo força vinculante igual à do preceito legislativo, pois vem munido

${ }^{9}$ DINIZ, Maria Helena. Curso de Direito Civil Brasileiro: direito das coisas. De acordo com o novo Código Civil. 17. ed. v.3. São Paulo: Saraiva, 2002. 
da norma legal representada pela possibilidade de execução patrimonial do devedor. Pacta sunt servanda! (RODRIGUES, 2002:18).

Segundo Maria Helena Diniz, de acordo com esse princípio, as estipulações feitas no contrato deverão ser fielmente cumpridas, sob pena de execução patrimonial contra o inadimplente. Esse posicionamento insere-se no contexto que, uma vez concluído livremente, incorpora-se ao ordenamento jurídico, constituindo uma verdadeira norma de direito. Esse princípio funda-se na regra de que o contrato faz lei entre as partes, desde que estipulado validamente, com a observância dos requisitos legais. Entretanto, tem-se admitido que a força vinculante dos contratos seja contida pelo magistrado em certas circunstâncias excepcionais ou extraordinárias que impossibilitem a previsão de excessiva onerosidade no cumprimento da prestação (Lei no ${ }^{\circ}$ 8.078/90, arts. 6º V, e 51; CC, arts. 478,479 e 480). ${ }^{10}$

2.3.4 - Princípio do consensualismo - princípio que integra a chamada teoria tradicional do contrato - é no liberalismo que este princípio ganha relevo e se firma como a regra para a formação dos contratos.

A grande contribuição para a admissão do princípio consensualista foi dada pelos canonistas, segundo os quais o descumprimento do contrato era a quebra de um compromisso equivalente à mentira, e, portanto, pecado.

$\mathrm{Na}$ Idade Média, o contrato sofreu muitas transformações. No tocante à exigência de formalidades, passaram as pessoas a entender que a menção do fato valia mais do que sua efetiva realização, "isto é, passou a ter mais valor a declaração de que as formalidades haviam sido observadas do que a verificação de sua prática efetiva".

2.3.5 - O princípio da igualdade - que teve como fundamento o dogma da autonomia da von- tade, foi desenvolvido, também, sob a concepção da igualdade entre os indivíduos perante a lei. $\mathrm{Na}$ verdade, a liberdade de contratar, como um reflexo do dogma da vontade, e a igualdade formal se encontram na base do próprio dogma, dando-lhe sustentáculo e coerência.

Como preleciona Alinne Novais (2002:64), uma vez concedido a todas as pessoas um poder livre e autônomo de atuar conforme sua vontade e, por conseguinte, a liberdade de contratar, tais pessoas foram colocadas em uma posição de igualdade, ainda que meramente jurídica. Assim, os indivíduos se viram libertos do grupo em que se inseriam na concepção feudal de sociedade e a todos eles, a partir de então, passou-se a atribuir uma qualidade jurídica que surgia com o próprio nascimento: a personalidade jurídica.

Ao contrário da concepção nominalista da igualdade, tese sustentada em obras da Grécia antiga, em Platão e depois em Aristóteles, bem como, com a concepção realista que traduz a última evolução no entendimento do sentido da igualdade, aceita atualmente a concepção liberal da igualdade, chamada, segundo nos noticia Luiz Renato Ferreira da Silva, de concepção idealista, entendia os homens como essencialmente iguais e que as desigualdades porventura existentes surgiam do convívio social e eram defeitos morais que se intrometiam na vida natural, defendendo, assim, um igualitarismo absoluto. ${ }^{11}$

2.3.6 - O princípio da boa-fé - nos termos do novo Código Civil, art. 422, reza que: "Os contratantes são obrigados a guardar, assim na conclusão do contrato, como em sua execução, os princípios de probidade e boa-fé". O direito positivo impõe que haja entre as partes uma colaboração no sentido de mútuo auxílio na formação e na execução do contrato, busca a boa-fé dos contratantes, a

\footnotetext{
${ }^{10}$ Idem, p. 40.

${ }^{11}$ É importante notar as diferenças entre as concepções ora aludidas. Assim explica o autor ora citado, ao se referir à concepção realista, complementando a idéia já exposta: "Nota-se a grande diferença entre esta concepção e as anteriores, especialmente a chamada idealista. É que para os realistas não há preeminência axiológica na igualdade frente à desigualdade. O que existe é uma relação acidental da coexistência de desigualdades que impõe a adoção de medidas que selecionem quais as desigualdades toleráveis. O instrumento adequado a tal missão não poderia deixar de ser a lei, com a afirmação do princípio da igualdade. A lei, que atua no âmbito da realidade, dos fenômenos sociais, não se preocupa, portanto, com a essencialidade e sim com os aspectos periféricos. A lei surge para enfrentar os debates no mundo do convício, nas situações de desigualdade".
} 
transparência negocial e a efetivação da justiça contratual, como nos ensina Jean-Luc Aubert.

\section{3- As Entidades de Previdência Complementar Fechada}

As Entidades Fechadas de Previdência Privada são sociedades civis ou fundações sem fins lucrativos, portanto pessoa jurídica de direito privado, destinadas à instituição de planos privados de concessão de benefícios complementares ou assemelhados aos da Previdência Social oficial, acessíveis aos empregados ou dirigentes, excluídos os diretores e conselheiros das Empresas Públicas, Sociedades de Economia Mista e Fundações vinculadas à Administração Pública, de uma empresa ou grupo delas, chamadas de patrocinadores.

O objetivo principal da EFPP, enquanto colaboradora do Poder Público Federal, é complementar os benefícios pagos pela Previdência oficial, evitando que o segurado tenha grande redução no seu padrão de vida, com a renda que possuía à época em que trabalhava.

\section{4 - Definição de Contrato Previdenciário}

Depois da análise da Teoria Geral Contratual, passamos ao estudo da entidade previdenciária fechada, quanto a sua natureza e regime jurídico, objeto desta monografia.

Conforme aponta o mestre Wagner Balera em Curso de Direito Previdenciário, homenagem a Moacyr Velloso Cardoso de Oliveira (2002:180), é considerada entidade fechada aquela criada no âmbito de empresas ou grupos delas, voltadas especificamente para o benefício de seus funcionários e dependentes, organizadas na forma de entidade não lucrativa.

E, continuando, o mestre em outra obra Sistema de Seguridade Social (2002:66), acentua que o plano previdenciário privado é figura contratual. Isto quer dizer, de índole contratual, negocial, engendrada e arrumada pelos interessa- dos, constituída de forma autônoma em relação ao regime geral de previdência social.

Nesse sentido, dispõe o art. 202 da norma fundamental:

Art. 202. O regime de previdência privada, de caráter complementar e organizado de forma autônoma em relação ao regime geral da previdência social, será facultativo, baseado na constituição de reservas que garantam o benefício contratado e regulado por lei complementar.

Neste sentido, depreende-se que no negócio jurídico previdenciário vigora o princípio da autonomia da vontade.

Com isso, podemos definir contrato previdenciário $^{12}$ como sendo o ato bilateral, que, pressupondo uma massa consistente de inscritos definida e garantida pelos órgãos do Sistema Nacional de Seguros Privados, uma pessoa (contratante) que deseja garantir-se ou garantir seus empregados, contra a materialização de certos e determinados riscos sociais ou thes criem estados de necessidade (participantes), acorda com uma pessoa jurídica legalmente autorizada a efetuar, no domínio privado, a compensação desses riscos (operadora), para o que lhe pagará, de uma só vez ou na forma de anuidades (mensalidades ou anualidades), uma importância (contribuição), tendo como contrapartida a obrigação da entidade pagar aos inscritos ou às pessoas que designarem (beneficiários) a respectiva compensação ou reparação, na forma de rendas ou de pecúlios (benefícios previdenciários).

Em compreensão ao texto elaborado, abstraise que as partes podem decidir, desde presente o elemento constitutivo do ato jurídico de contratar, a capacidade, sem qualquer tutela, a extensão, os limites e efeitos do negócio jurídico que engendram entre elas e que somente a elas diz respeito. (BALERA, 2002:67).

A norma fundamental, ao definir o negócio previdenciário privado como contrato, já exprime os elementos e pressupostos que revestirão, sob o império da autonomia da vontade, o comportamento humano, no particular.

\footnotetext{
${ }^{12}$ PÓVOAS, Manuel Soares. Na rota das instituições do bem-estar: seguro e previdência. São Paulo: Gren Forest do Brasil, 2000.
} 
É evidente que a norma fundamental, ao estabelecer o fato espécie (tipo contratual) previdenciária, definirá os termos do negócio privado (a norma de ordem pública, como fonte das obrigações).

Explicando melhor, a lei definirá os elementos externos do negócio previdenciário, deixando a talante das partes a manifestação da vontade contratual que afeiçoa o fato espécie genérico legalmente estabelecido ao querer que justificou a avença. (BALERA, 2002:68).

Nesse momento, justifica-se a segunda característica do negócio previdenciário privado, encontrando-se definida no art. 202 da norma fundamental qual seja a facultatividade.

Tal característica encontra-se revestida do disposto no princípio fundamental - da legalidade "ninguém poderá fazer ou deixar de fazer alguma coisa senão em virtude de lei".

O importante a ser objeto de análise é a distinção essencial entre o contrato das entidades fechadas das entidades abertas; esta distinção é estabelecida antes pelo tipo de plano que as mesmas podem implementar do que (como no direito anterior) pela relação previdenciária entre a mesma, seu instituidor ou patrocinador e os participantes.

Nesse sentido, é o que se encontra disposto no art. 12 e 13 da Lei Complementar nº 109/2001. Assim, as entidades fechadas são acessíveis a determinados grupos - sendo fechadas para os demais.

Isto quer dizer que é estabelecido um verdadeiro contrato social entre a entidade fechada e patrocinadores e instituidores que as tenham criado ou a ela tenham aderido. Este contrato (negócio jurídico) define as linhas gerais do plano previdenciário.

No entanto, o plano previdenciário privado deve expressar, em toda e qualquer das cláusulas que o regem, os objetivos fundamentais já definidos pela lei e pela regulamentação oficial da matéria - a norma fundamental (BALERA, 2002:77).

Nesse momento, passamos à análise dos elementos do contrato previdenciário.

\section{1 - Elementos do Contrato Previdenciário}

Conforme alude o mestre Póvoas (2000:314), o contrato de instituição de um plano empresarial ou, de uma forma mais geral, de um plano instituído por um empregador ou o contrato individual de inscrição num plano de benefícios é assemelhado ao contrato de seguros, apenas diferindo na terminologia.

Dessa forma, nos contratos de empresa, a pessoa jurídica empregadora é o contratante, e cada inscrito, o participante. Nos planos de entidades fechadas, como estas são instituídas por ato administrativo da empresa patrocinadora, o relacionamento jurídico com os inscritos é idêntico (PÓVOAS, 2000:314).

\subsection{1 - Participante}

Nos planos coletivos, a situação do participante não se altera, em face do disposto nos planos individuais, em que os contratos estipulam favor a terceiros (filhos e outros dependentes - pessoas diferentes dos participantes), na medida em que, não obstante a implantação do plano ter sido celebrado entre empregador e a operadora, cada participante celebra um contrato individual de inscrição com a operadora, que é a entidade que lhe garante que, perante a prova que preencheu as condições estabelecidas tanto para o ingresso no plano como para o recebimento do benefício, inclusive do resgate, o recebimento deles.

\subsection{2 - Entidade e Seguradora}

Representa a parte passiva da relação jurídica do contrato previdenciário privado, sendo esta definida na lei, ou a seguradora autorizada a operar planos previdenciários privados.

Como bem afirma Wagner Balera (2000:78), as entidades de previdência privada ganham vida no momento em que são autorizadas a funcionar pela autoridade competente. $\mathrm{O}$ reconhecimento é a prova cabal da natureza privada do ente, que se encontra revestido da forma prescrita na lei. 


\subsection{3 - Contratante}

A empresa que contrata com uma entidade aberta de previdência privada a inclusão num plano de benefícios previdenciários dos seus empregados e gerentes é a contratante e só tem que escolher os planos de benefícios instituídos pelas entidades, cujos regulamentos tenham sido aprovados pela SUSEP, aquele que melhor se adapte aos anseios dos seus servidores.

\section{5 - Conclusão}

Em razão do caos que assola a seguridade social do Brasil, e o intervencionismo estatal, surgem os planos de previdência complementar. A idéia dos participantes destes fundos é a manutenção do seu padrão de vida, quando da ocorrência de evento e infortúnio; sabe-se que a Previdência Oficial atualmente só garante um mínimo e, quando da verificação do evento, o beneficiário não consegue, absolutamente, manter seu padrão de vida nas mesmas bases de quando estava na ativa.

Esta garantia mínima de segurança para um futuro que está por chegar fez com que os fundos de pensão (previdência privada fechada) crescessem no país.

Entretanto, indaga-se: Seriam tais fundos de pensão a salvação para um padrão de vida melhor no futuro? Conforme estudos realizados por renomados juristas da área de Direito Previdenciário, a má administração e a falta de fiscalização dos fundos de pensão poderiam levar a um caos ainda maior do que aquele vislumbrado na Previdência Oficial.

Destaca Luis Eduardo Afonso em "Previdência Social e Fundos de Pensão." Cadernos de Seguro da Funenseg, ano I, jul. 1996, que:

a origem estatal dos grandes fundos é outro ponto merecedor de atenção. $O$ fato de os fundos terem se formado em estatais é até lógico, dado que os fundos começaram a se desenvolver, estas eram as grandes alavancas no crescimento econômico. O que não é lógico é o fato de os fundos serem tão grandes devido à ineficiência do setor estatal (previdência oficial). Em que pesem considerações a favor do papel social que tais empresas poderiam ter, estes argumentos servem na maioria dos casos para tornar mais evidente o deslocamento que o Estado brasileiro apresenta em relação à realidade que o cerca.

Sublinha-se, então, que, muitas vezes, o fundo de pensão de empresa estatal torna-se mais poderoso do que a própria empresa.

Outro argumento deve ser trazido à tona, já que a década de 90 foi marcada pelo processo de privatização de empresas estatais, compradas em leilão público por empresas privadas. Muitas privatizações em seus regulamentos não definiram obrigatoriamente a manutenção dos planos nos fundos de pensão, muito pelo contrário, o que se tem verificado na prática é a saída em massa das empresas privatizadas dos antigos fundos de pensão.

Isto remete a outra indagação: Se as empresas privatizadas não mantiverem os planos de pensão antigos, como sobreviverão tais entidades?

Contudo, uma alavanca para o crescimento econômico são os fundos de pensão gerados pelas empresas privadas que têm desempenhado seu papel e favorecido a vida dos trabalhadores, com base na segurança e confiabilidade de um futuro já assegurado.

Dessa forma, conclui-se que os sistemas de fundo de pensão no Brasil são considerados como o maior segmento de poupança institucional do País, tanto nos planos auto-administrados (previdência privada fechada), como nos planos administrados por instituições financeiras (previdência privada aberta).

A Previdência Complementar regulada pela Lei Complementar no 109/2001 tem o regime complementar autônomo e independente do Regime Geral da Previdência Social.

Incumbe ao Estado, pelo seu órgão fiscalizador, formular a política da previdência complementar, coordenar e supervisionar as atividades reguladas pela Lei Complementar, determinar padrões mínimos de segurança econômico-financeira e atuarial para liquidez, solvência e equilíbrio dos planos de benefícios, assegurar 
aos participantes e assistidos pleno acesso às informações de gestão e proteger os interesses dos participantes e assistidos dos planos de benefícios, fiscalizando as entidades fechadas e abertas e suas operações, ampliando-lhes penalidades previstas na Lei Complementar.

Quanto às entidades de previdência complementar fechada, estas são acessíveis aos empregados de uma empresa ou grupo de empresas e aos servidores da União, dos Estados, do Distrito Federal, e dos Municípios (pessoas jurídicas de direito público) e entes respectivos, da Administração indireta (autarquias, empresas públicas, sociedade de economia mista e fundações públicas). As empresas privadas ou entes governa- mentais que tiverem entidades fechadas são denominadas patrocinadoras. As entidades fechadas também podem ser criadas por pessoas jurídicas de caráter profissional, classista ou setorial, denominadas instituidoras e acessíveis aos seus respectivos associados ou membros.

Em suma, na Previdência Complementar fechada ou aberta, suas relações jurídicas entre contratante (os participantes) e a contratada (a entidade de previdência complementar - pessoa jurídica de direito privado) nascem do contrato e regem-se pelo Direito Privado em face da faculdade de sua contratação, tendo como objeto o beneficiário e a forma estabelecida na Lei Complementar 109/2001.

\section{REFERÊNCIAS BIBLIOGRÁFICAS}

AFONSO, Luis Eduardo. Previdência social e fundos de pensão. Cadernos de seguro da Funenseg, ano I, jul. 1996.

BALERA, Wagner. Sistema de seguridade social. 2. ed. São Paulo: LTr, 2002. . (Coord.) Curso de Direito Previdenciário. 5. ed. São Paulo: LTr, 2002.

DINIZ, Maria Helena. Curso de Direito Civil Brasileiro: direito das coisas. De acordo com o novo Código Civil (Lei n. 10.406, de 10-1-2002).17. ed. atual. v. 3. São Paulo: Saraiva, 2002.

NOVAIS, Alinne Arquete Leite. A teoria contratual e o Código de Defesa do Consumidor. São Paulo: Revista dos Tribunais, 2001. (Biblioteca de Direito do Consumidor).

PÓVOAS, Manuel Soares. Na rota das instituições do bem-estar: seguro e previdência. São Paulo: Green Forest do Brasil, 2000. REALE, Miguel. Filosofia do direito. 14. ed. atual. São Paulo: Saraiva, 1991.

RODRIGUES, Silvio. Direito civil. São Paulo: Saraiva, 2002.

VENOSA, Silvio da Salvo. Direito Civil: teoria das obrigações e teoria geral dos contratos. v. 2 . São Paulo: Atlas, 2001. (Coleção Direito Civil). 